\title{
THE SIGNIFICANCE OF ENTREPRENEURIAL LEADERSHIP AND SUSTAINABILITY LEADERSHIP (LEADERSHIP 4.0) TOWARDS MALAYSIAN SCHOOL PERFORMANCE
}

\author{
Norhisham Mohd Kasim ${ }^{1}$ \\ Faculty of Entrepreneurship \& Business, Universiti Malaysia Kelantan. \\ (Email: norhishambinmohdkasim@gmail.com) \\ Mohd Nazri Zakaria ${ }^{2}$ \\ Faculty of Entrepreneurship \& Business, Universiti Malaysia Kelantan. \\ (Email: mnazri.z@umk.edu.my)
}

Received date: 02-12-2019

Revised date: 03-12-2019

Accepted date: 04-12-2019

Published date: 12-12-2019

To cite this document: Kasim, N. M., \& Zakaria, M. N. (2019). The Significance of Entrepreneurial Leadership and Sustainability Leadership (Leadership 4.0) towards Malaysian School Performance. International Journal of Entrepreneurship and Management Practices, 2 (8), 27-47.

DOI: $10.35631 /$ ijemp. 28003

Abstract: School performance is the main agenda in school organizations in achieving the vision and mission as well as the main objectives of the Ministry of Education. Issues on performance in the context of school organizations are based on leadership management. The main issues highlighted are based on leadership in achieving the ultimate goal of the Ministry of Education (MOE). This study examines the leadership among the headmasters and principals in schools in improving the performance of schools in Malaysia. From the concept of leadership, the leadership that forms the leadership of entrepreneurship among teachers in every school leader plays an important role in the education system to deal with changes and challenges. Entrepreneurial leadership is a leader who is classified to achieve the same goal of using entrepreneurial behavior. Hence, this study focuses entirely on entrepreneurial leadership relationships with school performance in Malaysia. This study also tests the sustainability leadership as a second variable. Supported by the Model LeaderMember Exchange theory, this study proposes a framework by outlining the factors that exist in entrepreneurial leadership and sustainable leadership A total of 171 school organization from public schools have participated in this study. Data for this study variables were collected through a self-administered survey. Partial Least Square - Structural Equation Modeling (PLS-SEM) is the main statistical technique used in this study. The findings show that some variables such as entrepreneurial leadership and sustainability leadership are significant in relation to school performance. The findings will contribute to future research that researchers can research deeply on leadership 4.0 towards the performance of public or private schools in Malaysia. 


\section{Introduction}

Revolution Industry 4.0 is currently a top priority in increasing transformability and responding to demographic change for many organizations, research centers and education. Majority of experts in the academia believe that the Revolution Industry 4.0 term itself is unclear and manufacturing firms are facing difficulties when it comes to understanding this phenomenon and identifying the steps required for the transition towards Industry 4.0. Gilchrist (2016), Liao et al. (2017), Santos et al. (2017), Ustundag and Cevikcan (2017) and Vogel-Heuser and Hess (2016) believe that Revolution Industry 4.0 can be defined and identified based on its design principles and technology trends. To identify the key design principles and technology trends of Revolution Industry 4.0, globalised world has called organizations to look for ways to compete more effectively on performance.

Academicians have identified several issues regarding to the organization performance. They have identified performance from global perspective issues which highlighted by three main factors leadership, process and result (Hocevar, Janzen \& Wilson, 2012). However Lu, Zhu and Bao (2015) mentioned that performances are distinguished by excellent leadership and dynamic leaders who are committed to the success of organizational variables. The effective leader is a leader who played a role as a visionary leader who is clear about his organization, employees and result. Performance in school organization also distinguished by excellent leadership and dynamic leaders in controlling their process and students achievement towards effectiveness school (Rahimah \& Ghavifekr, 2014). The issues of leadership towards performance are similarity to the factors contribute to the school performance. There are a lot of factors that significance to the school performance excluding leadership. Shaked and Schechter (2014), mentioned that leadership element needs to investigate because of not influencing indirectly and evaluating significance toward school performance. In general requirement of the demands to improve the performance of the school is very urgent especially with the availability of internationally competitive today (Jones \& Harris, 2014).

The issue of preparing and developing school leaders has a long history of research and empirical inquiry in the performance perspective. Malaklolunthu and Shamsudin (2011) emphasize the importance of developing school and need to investigate for school leaders in their distinctive role as educational leaders. This same priority is reflected in Malaysia, as a new mandatory qualification, the National Professional Qualification for Educational Leaders (NPQEL), for all new school leaders has recently been introduced (Institut Aminudin Baki, 2014). Leithwood and Sun (2012) reinforce that leadership strategies are crucial, within an educational setting, to secure better performance and outcomes. As emphasized earlier, school leaders in Malaysia are now viewed as transformational leaders who are expected to lead change and improve performance in line with national expectations (Malaklolunthu \& Shamsudin, 2011). This means that, Malaysia school leaders are now expected to bring about change in their schools and to improve school performance year on year (Tie, 2012). Malaysia are now expected to create the different leadership in developing the goals, mission and values of the school toward to the global challenges as the transformational (Rahimah \& Ghavifekr, 2014). Therefore, Pihie et al., (2014) introduce a different leadership in school organization as an entrepreneurial leadership in facing all the barriers, environment and global challenges in order to improve the school performance. 
There are several studies regarding to the elements of entrepreneurial leadership regarding to the performance and achievement of the organization. Park (2012) found a significant relationship between school leaders and support for innovation at schools. Eyal and Inbar (2013) found that the relationship between primary school principals' proactiveness and school innovativeness. They defined school principals' proactiveness as the willingness to start intrinsically motivated actions and found that proactive leadership has a good impact in improving a school organization. Keempster and Cope (2010) mentioned that risk taking is the best of the willingness of entrepreneurial leadership to absorb uncertain environment and take on big responsibility and challenge for the future. In addition, entrepreneurial leadership is considered as having a superior tendency to take risks than cope and need to take a different risk in a various platform of their project and organization growth. Renko, Tarabishy, Carsrud and Brannback (2015) mentioned that creativity in entrepreneurial leadership was influencing and directing the performance of group members towards the achievements of those organizational goals which involve recognizing and exploiting entrepreneurial opportunities.

Fontana et al., (2017) mentioned that innovation of entrepreneurial leadership has a significance relationship to the performance, Ruvio et al., (2010) mentioned that entrepreneurial leadership has significance relationship to the non-profit organization. Renko et al., (2015) also mentioned that creativity of entrepreneurial leadership has a significance relationship to the organization. Based on the argument of the relationship between the elements of entrepreneurial leadership, conclude that dimension of entrepreneurial leadership has significance relationship toward organization achievement either in profit or non-profit organization.

This study also needs a different leadership toward the organization performance. The priority of this second leadership in this study based on the argument of the past research of the element of entrepreneurial leadership and performance. First, Renko et al., (2015) mentioned in their recommendation that entrepreneurial leadership needs an element as resilience toward organization performance. School leaders currently face new challenges arising from the new transformational agenda. For the example, measurement of school performance based on Key Performance Index (KPI) and student achievement. In order to meet such demands now, more than ever, school leaders need to have the high resilience necessary to ensure lead transformation and change (Anthony et al., 2015).

Second, Kozlowski (2014) mentioned in the recommendation that entrepreneurial leadership needs decision making the element to achieve the performance. Despite such investment in school leaders preparation and strategies in Malaysia, the empirical evidence about its impact and indeed any contemporary, independent evidence about the decision making of school leaders remain relatively limited. A recent review of the leadership literature in Asia has highlighted an urgent need for more systematic research into the decision-making of leaders in many countries, including Malaysia (Hallinger \& Chen, 2015). Consequently, this outlines emerging empirical evidence about school leadership practices in Malaysia as part of a larger, contemporary study of leadership preparation and strategies. These elements may also prove important for the development of entrepreneurial leadership and agreed by Anthony, Said, Mohamad and Mokhtar (2015); Hallinger and Chen (2015). Based on the elements of resilience and decision-making, Avery et al., (2011) mentioned that the two elements are related to the sustainability leadership. Therefore, Suriyankietkaew (2016) propose that the increase in school leaders accountabilities has created a need for sustainability leadership. A growing trend of international literature on sustainability leadership suggests that it is one of 
the most popular leadership models of the twenty-first century (Bush and Glover (2012). Kantabutra and Saratun (2013) mentioned that sustainability one of the factors in leadership can increase the performance of the organization.

Therefore this study contributes the integrated model of entrepreneurial leadership and the second independent variable of sustainability leadership based on recommended past research, Renko et al., (2015); Pihie et al., (2014); Kozlowski (2014) and Men et al.,(2013).

\section{Theory Development And Hypotheses}

\section{The Relationship of Entrepreneurial Leadership towards School Performance}

Entrepreneurial leadership is a distinctive type of leadership required for dealing with challenges and crises of the current organizational setting. This leadership style enables leaders to successfully direct their organization and solve the problems through different steps of the organization's growth and development. It also has great influence on leaders' competency in recognizing new opportunities to improve the organization's performance (Soane, Butler \& Stanton, 2015). These influential effects have led scholars to increasingly apply entrepreneurial leadership to improve various aspects of education and specifically school performance (Mastrangelo, Eddy \& Lorenzet, 2014). Entrepreneurial leadership has been emphasized to create a supportive environment for change and innovation at schools (Jena \& Sahoo, 2014).There are different complexities and challenges of school organization such as higher demands for improving the quality of education in public schools, fast changes in the environment and growing shortages in school resources and funds (Kansikas, Laakkonen, Sarpo \& Kontinen, 2012). Researchers believe that school performance require entrepreneurial leadership characteristics and the knowledge and competence to execute their tasks based on leadership. Researchers also looked at the benefits of entrepreneurship for school performance in two ways. Firstly, entrepreneurship in general and entrepreneurial leadership in particular have been considered as ways of thinking and lifestyle rather than merely establishing organization (Castelli, 2015). In this sense, entrepreneurial characteristics and approaches can be applied to improve all aspects of education and schooling, specifically school leadership through influencing individuals' behaviours and their task performances (Ng, Thorpe, 2010).

Accordingly, school leaders need to acquire and practice entrepreneurial leadership characteristics in order to improve their school effectiveness and to facilitate the process of quality school. Secondly, past researchers have focused on the advantages of organizational entrepreneurship for school organization improvement (Mastrangelo, Eddy \& Lorenzet, 2014). In this context, organizational performance reflects the capacity of a school to develop and implement novel ideas that lead to critical changes and improvements at the school (Jarvet \& Murphy, 2014). School performance has three main components including the capacity to explore new educational opportunities, the tendency to take action and exploit the opportunity and the changes that implemented innovations created in the school performance (Kurland, Peretz \& Lazarowitz, 2010). Therefore, entrepreneurship features are applied in school organizations to enhance their success in providing quality leaders and learning environment. Entrepreneurial leadership competencies, help school leaders to face the complexities and constraints of the school environment such as fast pace changes, limited resources, the variety of factors affecting school performance and the urgency in need for preparing learners for their highly competitive future (Xaba \& Malindi, 2010). These competencies also enable school leaders to create the dramatic changes and innovations required in public schools by looking beyond the current status of the school and developing 
new opportunities for school improvement (Mitchelmore \& Rowley, 2010). While the first approach looks at the critical role of individuals in adopting entrepreneurial behaviours, the second approach highlights the importance of entrepreneurial elements in the school organization. Past studies on the innovations implemented in schools have provided empirical evidence that they cannot fundamentally change and improve school performances (Burnes \& Donnell, 2011). This can be partially attributed to school leadership that has failed to provide supportive environment for changes and innovations in the school (Park, 2012). In a recent study, Xaba and Malindi (2010) specified entrepreneurial characteristics of the principals in history has advantaged schools. Fontana et al., (2017) and Park (2012) found a significant relationship between innovation to the performance. Innovative has been well defined as the quality and ability of the entrepreneurial leadership to think differently, creatively and develop performance of organization. Eyal and Inbar (2013) found that the relationship between primary school principals' proactiveness and school innovativeness. They defined school principals' proactiveness as the willingness to start intrinsically motivated actions, which are not imposed by the authorities and school innovativeness as the perceived amount of innovations implemented in school during a given time. They found that proactive leadership has a good impact in improving a school organization.

Keempster and Cope (2010) mentioned that risk taking is the best of willingness of entrepreneurial leadership to absorb uncertain environment and take on big responsibility and challenge for the future. In addition, entrepreneurial leadership are considered as having a superior tendency to take risks than cope and need to take different risk in various platform of their project and organization growth. Renko, Tarabishy, Carsrud and Brannback (2015) mentioned that creativity in entrepreneurial leadership were influencing and directing the performance of group members towards the achievements of those organizational goals which involve recognizing and exploiting entrepreneurial opportunities. Many researchers proof in their research that communicative of the leadership related to the vision of future possibilities and shared throughout the organization performance. The communicative of leaders deals to the ability to persuade followers of the organization, to manage conflicts and to foster knowledge management by understanding emotions in social interactions (Musa \& Fontana, 2014). Communication is important for effective entrepreneurial leadership, which it first deals with influencing others toward a goal through persuasion for upward, lateral and downward influence. Communicative of entrepreneurial leadership shares vision of future possibilities enables an organization to transform its current transaction sets through adaptation and leading, through direct involvement, a process of value creation for the stakeholders employing innovation to achieve goal and organization performance (Hejazi et al., 2012). Motivational of entrepreneurial leaders related to the human action within the organization that affects both motivation and cognition of people in the organization performance. Musa and Fontana (2017) stated that motivation leaders play a critical role in the entrepreneurial process toward the organization achievement. It addresses the ability to motivate people in the organization, to understand the needs of the organization, to maintain an entrepreneurial spirit in people within the organization and to have the self-confidence to influence others.

Personal of entrepreneurial leaders related to the creativity, stability, proper resource allocation and discipline. Creativity deals with the creative skills to organize the needed resources and enact the role of framing the challenge. Stability refers to emotional stability at the individual level, passion and the commitment of the organization to entrepreneurial activities. Proper resource allocations refers to managing resources and maintaining dynamic capabilities to enhance knowledge management within the organization, which in turn could 
support efforts to recognize opportunities, while organizational discipline deals with building a bridge that links entrepreneurship and strategic management. The creativity, proper resource allocation and disclipline in the personal of the entrepreneurial leaders will enhance the organization performance (Hejazi et al., 2012).Strategic of entrepreneurial leaders refer to the ability to determine the organization system in a comprehensive manner taking into account resources, people and strategy toward organization success. The strategic leaders also addresses strategic thinking that entrepreneurial leaders must have to ensure the vision of future possibilities that is shared, so that the organization will have a sense of direction, destiny, discovery and goals achieve (Musa \& Fontana, 2017). As the conclusion, leaders in such schools unconsciously practice innovativeness, proactiveness, creativities, risk taking, strategic, communicative, personal and motivational in order to overcome the constraints in the school environment, particularly in relation to the required resources.

\section{The Relationship of Sustainability Leadership towards School Performance}

Researchers also have proven in their recommendation finding that sustainability leadership can be a new variable of leadership. Suriyankietkaew et al., (2014) suggest that sutainability in competence and control the leadership and reputation in the organization. Furthermore, sustainability also significance relationship between leadership and innovative work behaviour. The suggestion also supported by Kantabutra et al, (2013) that sustainability also influence of leadership on the engagement of effective commitment with the health service workers sampling. The resilience of sustainability leadership partially significance the relationship of leadership behaviour and intention to stay (Opuku et al., 2015). The resilience sustainability leadership can be seen as the respective cause and effect of insinuating that leaders can have an influence on the empowering experiences of the subordinates developmental (Horward \& Irving, 2012). The resilience effect the relationship between transformational leadership and followers' welfare (Dartey- Baah, 2015). Several studies have shown that decision making is suitable for the variable of leadership relationship. There are essentially two types of sustainability leadership given as resilience and decision making (Metsamuuronen et al., 2013; Avery et al., 2011).

Researchers also found that sustainability and leadership will enhance subordinate work motivation and performance through the delegating authority for job related to decision making (Metsamuuronen, Kuosa \& Laukkanen, 2013). Benn et al., (2013) mentioned that emphasize on leadership and sustainability in education context is in similar fashion for organization success. The previous studies also give the suggestion that leadership influences sustainability organization through sustain them (Kantabutra et al., 2013). According to the Wang (2014), leadership can sustain their organization by articulating clear organization future goals, generating employee enthusiasm for worthy causes and expressing high performance expectation from employee. Sustainability positively associated to the achievement, whereas leadership is inversely associated with perceived crisis proneness (Herrera-Cano, 2016). Avery et al., (2011); Metsamuuronen et al., (2013) founded that sustainability leadership components including resilience and decision making are found to be significantly related to innovation performance. Accordingly, when a leader perceives that their requirements are meaningful and personally valuable, they can increase their achievement by willingly spending time and effort necessary to thoroughly identify a problem, search for extensive information, and generate multiple ideas from different perspectives. According to the (Strand, 2014), sustainability is positively associated with strategic in performance. (Hoii et al., 2016) founded that sustainability leads to orientation towards job, management and organization. Luoh (2014) also mentioned that sustainability play a buffering role relationship to the innovative performance. In addition, sustainability 
may enhance employees intrinsic motivation, leading to a higher level of innovation performance (Tideman, 2016).

Galpin and Whittington (2012) found that a majority of respondents believe sustainability is becoming increasingly important to leaders and that the risks of failing to act on are achievement growing. The pressure organization feel to implement sustainability leadership practices too often results in a jumble of uncoordinated sustainability activity, disconnected from the firm's strategy that neither make any meaningful social impact nor strengthen the firm's long-term competitiveness. If a firm's sustainability efforts are to provide long-term value to both the organization and society, sustainability must be integrated into the firm's strategy. Gerard et al., (2017) mentioned that communicative in decision making are the main elements in ensuring successful teamwork can be achieved. Additionally, the relationship between communication leaders an employee as crucial for enhanced sustainability leadership and organization performance. Sustainability leadership has effects on workforce performance for the unleashing creativity energy. Specially, information about the organization mission and performance are crucial for sustainability (Banker et al., 2014). In addition, the empirical findings demonstrate that organization performance more positively when they perceived their leaders to be high on resilience (Dartey-Baah, 2015). (Eilers et al., 2016) mentioned that the measurement of performance system has positively influence the sustainability. The concept of sustainability is able to foster leaders in active work role, sustain their organization and support the effective governance of organization. Wang (2014) demonstrated that sustainability is positively related to the employees' task, contextual and innovation performance. The relationship between sustainability, innovation performance was found to have been significant by locus of control (Banker et al., 2014). A distinction was made between organisational sustainability as a bundle of HRM activities and decision making as leaders work related performance. Hence, their role in the performance linkage was defined. Resilience and decision-making sustainability leadership was positively related to the HRM performance, job satisfaction, and affective commitment (Avery et al., 2011; Metsamuuronen et al., 2013). As the conclusion, leaders in such schools unconsciously resilience and decision making in order to overcome the constraints in the school environment, particularly in relation to the required resources.

Specifically, this hypothesis is:

\section{H1 Entrepreneurial leadership has significant relationship towards school performance.}

H1a: Innovative has positive relationship to the school performance.

H1b: Proactiveness has significant relationship with school performance.

H1c: Risk taking has significant relationship to the school performance.

H1d: Creativity has positive significant towards school performance.

H1e: Communicative has positive relationship to the school performance.

H1f: Personal has significant relationship with school performance.

H1g: Strategy has significant relationship to the school performance.

H1h: Motivational has positive significant towards school performance.

\section{H2 Sustainability leadership has significant relationship towards school performance.}

$\mathrm{H} 2$ a: Resilience has positive relationship towards school performance. 
$\mathrm{H} 2 \mathrm{~b}$ : Decision making has positive relationship towards school performance.

\section{Research Objective}

Generally, this research is focusing on the relationship between entrepreneurial leadership and sustainability leadership toward school performance of school leaders in Malaysia. The research objectives are:

a) To determine the influence of entrepreneurial leadership (innovative, proactive, creative, risk taking, strategy, communicative, motivational \& personal) towards Malaysia school performance.

b) To determine the influence of sustainability leadership (resilience \& decision making) towards Malaysia school performance.

Table 2.0 Framework

\section{Entrepreneurial Leadership}
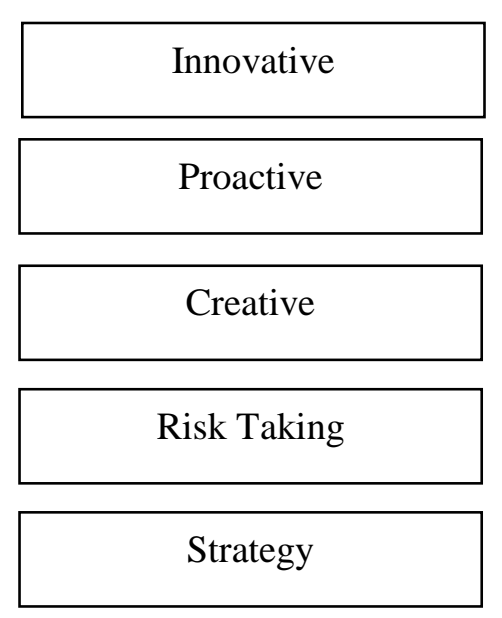

Communicative

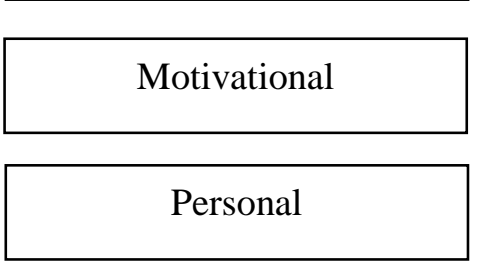

Sustainability Leadership

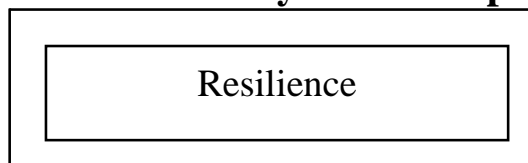

Decision Making

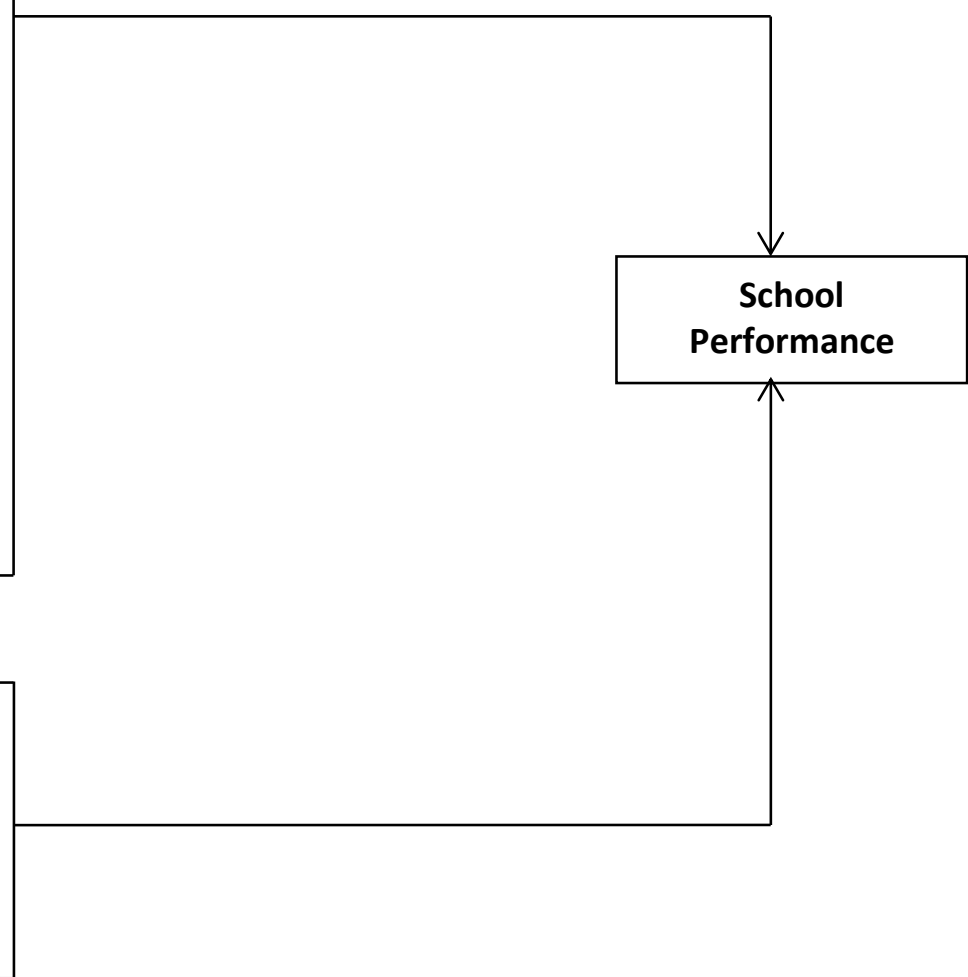




\section{Methodology}

\section{Study Population and Sample Size}

The population public school in Malaysia for the primary school is 7772 schools and secondary school is 2436 school. The total for the primary and secondary is 10, 208 school (Data EMIS 31 January 2019, Education of Malaysia). However, the population in this study only for the four states in Malaysia which is Perlis, Johor, Wilayah Persekutuan Labuan and Wilayah Persekutuan Putrajaya. The population school for this study is 196 schools. The sample size for this study is the school administrators of the school in Malaysia public school. The school administrator is Senior Assistant of Administration. The administrator selected based on middle position in evaluate their headmaster or principal which representing the school organization. These school organization selected categorised the school lowest and highest awarded excellence cluster school and high-performance school.

Table 1.2 Sample Size

\begin{tabular}{lccc}
\hline \multicolumn{1}{c}{ State } & Secondary School & Primary School & Total \\
\hline W.P Putrajaya & 11 & 14 & 25 \\
W.P Labuan & 10 & 17 & 27 \\
Perlis & 30 & 74 & 10 \\
Johor & 20 & 20 & 40 \\
Krejcie and Morgan Table $(196=200)$ & & $\mathbf{2 0 0} \boldsymbol{N}=\mathbf{1 3 6} \boldsymbol{S}$ \\
\hline
\end{tabular}

\section{Measurement}

\section{School Performance}

School performance is measured with 22 items across the five dimensions namely leadership and direction ( 8 items), organization management (5 items), education programme management (3 items) learning and teaching (3 items) student achievement (3 items). The questionnaires were adapted from Malaysia Education Standard Quality (2010) and supported by Sammons, Hilman \& Mortimore (1995).

\section{Entrepreneurial Leadership}

Entrepreneurial leadership is measured with 53 items across the eight dimensions namely creative ( 3 items), risk taking (3 items), proactive ( 8 items), innovative (4 items), strategic (10 items), communicative ( 9 items), motivational (7 items) and personal (9 items). The questionnaires of entrepreneurial leadership items were adapted from Thornberry (2006); Fernald, Solomon and Tarabishy (2005); Tierney and Farmer (2004); Gupta, MacMillan and Surie (2004);Becherer, Mendenhall and Eickhoff (2008); Chen (2007); D'Intino, Boyles, Neck, Hall (2008); Mumford (2002); Cogliser and Brigham (2004); McGrath and MacMillan (2000) ; Musa and Fontana (2014) ; Hejazi, Maleki and Naeiji (2012).

\section{Sustainability Leadership}

Sustainability leadership is measured with 11 items across the two dimensions namely resilience (6 items) and decision making (5 items). The questionnaires of sustainability leadership dimension were adapted The Connor- Davidson Resilience Scale (CD-RISC) Connor and Davidson (2003); Smith, Dalen, Wiggins, Tooley, Christopher and Bernard 
(2008); General Decision-Making Style (GDMS) Scoot and Bruce (1995); Verma, Bhat, Rangnekar and Barua (2015).

\section{Finding and Result}

\section{Common Method variance}

As this study adopted a self-report, single-informant approach in gathering data, it was necessary to check for the possibility of common method bias (MacKenzie \& Podsakoff, 2012). To address this problem, Harman single factor test was conducted to determine the existence of it. According to MacKenzie \& Podsakoff (2012), common method bias is problematic if a single latent would account for the majority of the explained variance. The unrotated factor analysis performed on all measurement items, extracting 15 factors with eigenvalues greater than 1.0 as shown in the table 4.1. Thus, based on result of common method variance was not a serious problem in this study.

Table 4.1: Harman's One Factor Test-Total Variance Explained (CMV)

\begin{tabular}{cccc}
\hline Factor & Total & $\begin{array}{c}\text { Initial Eigenvalues } \\
\text { Variance }(\%)\end{array}$ & Cumulative (\%) \\
\hline 1 & 13.137 & 77.278 & 77.278 \\
2 & .897 & 5.275 & 82.552 \\
3 & .512 & 3.014 & 85.566 \\
4 & .372 & 2.188 & 87.754 \\
5 & .329 & 1.933 & 89.687 \\
6 & .296 & 1.742 & 91.429 \\
7 & .250 & 1.471 & 92.901 \\
8 & .234 & 1.375 & 94.276 \\
9 & .204 & 1.200 & 95.477 \\
10 & .185 & 1.087 & 95.564 \\
11 & .153 & .902 & 97.467 \\
12 & .121 & .714 & 98.181 \\
13 & .107 & .627 & 98.808 \\
14 & .053 & .310 & 100.000 \\
15 & .055 & .326 & 100.000 \\
\hline
\end{tabular}

\section{Measurement Model}

Based on PLS measurement analysis, show that the absolute correlation between the construct and its measuring manifest items (factor loading) was above than the minimum threshold criterion 0.4 . The factor loading was ranging from 0.546 to 0.899 and satisfied the requirement of the psychometric reliability test. According to table 4.2 shown that four items was removed because factor loading value is not fulfil the condition (less 0.6). These items are from latent variable strategic ( 1 item), innovative $(1$ item) and school performance (2 items). 


\section{Hypothesis Testing}

Table 4.2 Second Order Result of Hypothesis Testing Entrepreneurial Leadership to School Performance

\begin{tabular}{|c|c|c|c|c|c|}
\hline Hypothesis & $\begin{array}{c}\text { Path } \\
\text { Relationship } \\
\text { Between } \\
\text { Variables } \\
\end{array}$ & 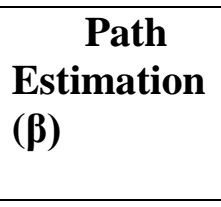 & $\begin{array}{c}t \\
\text { Value }\end{array}$ & $\begin{array}{c}p \\
\text { Value }\end{array}$ & Results \\
\hline $\mathrm{H} 1$ & EL->SP & $0.657 * * *$ & 9.556 & 0.000 & Supported \\
\hline $\mathrm{H} 1 \mathrm{a}$ & $\mathrm{RT}->\mathrm{SP}$ & 0.015 & 0.550 & & Not \\
\hline \multirow[t]{2}{*}{$\mathrm{H} 1 \mathrm{~b}$} & CRE->SP & -0.260 & 1.065 & $\begin{array}{c}0.583 \\
0.287\end{array}$ & $\begin{array}{l}\text { Supported } \\
\text { Not }\end{array}$ \\
\hline & & & & & Supported \\
\hline H1c & PRO->SP & $0.613 * * *$ & 5.196 & 0.000 & Supported \\
\hline \multirow[t]{2}{*}{ H1d } & INO->SP & 0.005 & 0.081 & 0.935 & Not \\
\hline & & & & & Supported \\
\hline H1e & COM->SP & $-0.068 * *$ & 2.108 & 0.036 & Supported \\
\hline H1f & PER->SP & $0.261 * * *$ & 4.392 & 0.000 & Supported \\
\hline $\mathrm{H} 1 \mathrm{~g}$ & STR->SP & $0.072 * *$ & 2.278 & 0.023 & Supported \\
\hline $\mathrm{H} 1 \mathrm{~h}$ & MOT->SP & -0.028 & 0.243 & 0.808 & Not \\
\hline
\end{tabular}

Supported

Note: Significant level $=* * * \mathrm{p}<0.01 ; * * \mathrm{p}<0.05 ; * \mathrm{p}<0.10 ;$ not significant.

$\mathrm{EL}=$ Entrepreneurial Leadership; $\mathrm{SP}=$ School Performance; $\mathrm{INO}=$ Innovative $; \mathrm{PRO}=$ Proactive $; \mathrm{CRE}=$ Creative;

$\mathrm{COM}=$ Communicative, $\mathrm{PER}=$ Personal; $\mathrm{STR}=$ Strategic $;$ MOT = Motivational .

In supporting $\mathrm{H} 1 \mathrm{a}$ to $\mathrm{H} 1 \mathrm{~h}$, this study discovers a relationship between variables of entrepreneurial leadership towards school performance. The result of structural relation and path significance, the t-value and their significance level, p-value shown in Table 4.3. In addition, the result also revealed that the entrepreneurial leadership variable provides an evidence that significant support to school performance. However, the dimension of risk taking, creative, innovative and motivational provides evidence not significance toward school performance. 


\section{Table 4.3 Second Order Result of Hypothesis Testing Sustainability Leadership to School Performance}

\begin{tabular}{lccccc}
\hline Hypothesis & $\begin{array}{c}\text { Path } \\
\text { Relationship } \\
\text { Between } \\
\text { Variables }\end{array}$ & $\begin{array}{c}\text { Path } \\
\text { Estimation } \\
(\boldsymbol{\beta})\end{array}$ & $\begin{array}{c}\boldsymbol{t} \\
\text { Value }\end{array}$ & $\begin{array}{c}\boldsymbol{p} \\
\text { Value }\end{array}$ & Results \\
\hline $\mathrm{H} 2$ & $\mathrm{SL}->\mathrm{SP}$ & $0.414^{* * *}$ & 7.587 & 0.000 & Supported \\
$\mathrm{H} 2 \mathrm{a}$ & $\mathrm{RES}->\mathrm{SP}$ & $0.544^{* * *}$ & 7.704 & 0.000 & Supported \\
$\mathrm{H} 2 \mathrm{~b}$ & $\mathrm{DM}->\mathrm{SP}$ & $0.434^{* * *}$ & 6.607 & 0.000 & Supported \\
\hline
\end{tabular}

Note: Significant level $=* * * p<0.01 ; * * p<0.05 ; * p<0.10 ;$ not significant.

$\mathrm{SL}=$ Sustainability Leadership; $\mathrm{SP}=$ School Performance; RES = Resilience; $\mathrm{DM}=$ Decision Making

As can be seen from Table 4.3, this study discovers that the relationship between sustainability leadership to school performance is significant. In addition, the result also revealed that sustainability leadership provide an evidence that significant support to school performance. The resilience dimension of sustainability leadership also provides a significant support to the school performance and decision making of sustainability leadership also provide a significant support to the school performance.

\section{Conclusion}

\section{Discussion}

The finding of this study demonstrate that entrepreneurial leadership provide significant relationship toward school performance in Malaysia. Back to the literature mentioned that entrepreneurial leadership is a distinctive type of leadership required for dealing with challenges and crises of the current organizational setting. The different leadership style enables leaders to successfully direct their organization and solve the problems through different steps of the organization's growth and development. The result also support the statement from Soane, Butler and Stanton (2015) which mentioned that this style of leadership has great influence on leaders competency in recognizing new opportunities to improve the organizations performance. The result also supports the literature which mentioned by Mastrangelo, Eddy and Lorenzet (2014), influential effects have led scholars to increasingly apply entrepreneurial leadership to improve various aspects of education and specifically school performance. In this study conclude that school performance require entrepreneurial leadership characteristics and the knowledge and competence to execute their tasks based on leadership. Castelli (2015) mentioned that the benefits of entrepreneurship for school performance in two ways. Firstly, entrepreneurship in general and entrepreneurial leadership in particular have been considered as ways of thinking and lifestyle rather than merely establishing organization. The entrepreneurial characteristics and approaches can be applied to improve all aspects of education and schooling, specifically school leadership through influencing individuals' behaviours and their task performances (Ng, Thorpe, 2010). The result in this study also agree that school leaders need to acquire and practice entrepreneurial leadership characteristics in order to improve their school effectiveness and to facilitate the process of quality school. Secondly, this study found that the advantages of organizational entrepreneurship for school organization improvement (Mastrangelo, Eddy \& Lorenzet, 2014). School performance reflects the capacity of a school to develop and 
implement novel ideas that lead to critical changes and improvements at the school (Jarvet \& Murphy, 2014). This study also agreed by Kurland, Peretz and Lazarowitz (2010) that school performance has three main components including the capacity to explore new educational opportunities, the tendency to take action, exploit the opportunity and the changes that implemented innovations created in the school performance. Entrepreneurship features are applied in school organizations to enhance their success in providing quality leaders and learning environment. Entrepreneurial leadership competencies, help school leaders to face the complexities and constraints of the school environment such as fast pace changes, limited resources, the variety of factors affecting school performance and the urgency in need for preparing learners for their highly competitive future (Xaba \& Malindi, 2010). These results also support the literature that school leaders to create the dramatic changes and innovations required in public schools by looking beyond the current status of the school and developing new opportunities for school improvement (Mitchelmore \& Rowley, 2010).

In this study, the result for the innovation of entrepreneurial leadership show the not significant relationship toward school performance. The result of hypothesis not support the literature of the innovations implemented in schools have provided empirical evidence that they cannot fundamentally change and improve school performances (Burnes \& Donnell, 2011).The innovation of entrepreneurial leadership can be partially attributed to school leadership to provide supportive environment for changes and innovations in the school (Park, 2012). Xaba and Malindi (2010) specified an innovative entrepreneurial characteristic of the principals in history has advantaged schools. However, the hypothesis result not support the literature by Musa et al., (2017) and Park (2012) that innovative have a significant relationship to the performance. This not significant result because of the school leaders are weak in in radical improvement ideas for the performing school. The result highlighted that some school leaders still weak in bring the teachers challenge the current way in teaching and still weak in push teachers to act in more innovative ways.

The findings in this study also support the literature by Eyal and Inbar (2013) that the relationship between proactiveness and school performance. They defined school principals' proactiveness as the willingness to start intrinsically motivated actions, which are not imposed by the authorities and school innovativeness as the perceived amount of innovations implemented in school during a given time. They found that proactive leadership has a good impact in improving a school organization performance. The risk taking hypothesis result show that is not support the past study in the literature. The literature by Keempster and Cope (2010) mentioned that risk taking is the best of willingness of entrepreneurial leadership to absorb uncertain environment and take on big responsibility and challenge for the future. In addition, entrepreneurial leadership are considered as having a superior tendency to take risks than cope and need to take different risk in various platform of their project and organization growth. However, the result in this study show that risk taking are not supported in context because of the different context of profit and non-profit context. This is because in non-profit context, their need to incorporate techniques of not just risk management but also uncertainty management within their diligence activities around decision-making. In profit context, entrepreneurial activity is never dependent on a known future or known facts, entrepreneurial risk-taking incorporates action taken by enterprises that facilitate the transformation of uncertainties into opportunities (Marshall \& Ojiako, 2015). The result in chapter four also not agreed the finding by Renko, Tarabishy, Carsrud and Brannback (2015) that creativity in entrepreneurial leadership were influencing and directing the performance of group members towards the achievements of those organizational goals which involve recognizing and exploiting entrepreneurial opportunities. The literature approves that creativity are important 
element as an effective leader in school organization. Leaders need to creation of powerful learning environments Leaders differ in their creative problem solving style, manage their style for the significant effect on school performance, The most creative effective leaders of the $21^{\text {st }}$ century will help leaders to coordinate and integrate their differing style to drive change through a process of applied creativity that includes continuously discovering and defining new problems, solving those problems and implementing the new solutions. The result highlighted that some of school leaders still weak to become a creative person in school issues solution. The school leaders need to create processes that enable to bypass the unnecessary rule, regulations and bureaucratic nonsense of the school. The school leaders also need create a culture in which teachers are rewarded for trying new and different things even if they do not work in the end.

Many researchers proof in their research that communicative of the leadership related to the vision of future possibilities and shared throughout the organization performance. The result of the communicative dimension to school performance agreed that communicative of leaders deals the ability to persuade followers of the organization, to manage conflicts and to foster knowledge management by understanding emotions in social interactions (Musa \& Fontana, 2017). The finding also support by Hejazi et al., (2012) that communication is important for effective entrepreneurial leadership, which it first deals with influencing others toward a goal through persuasion for upward, lateral and downward influence. Communicative of entrepreneurial leadership shares vision of future possibilities enables an organization to transform its current transaction sets through adaptation and leading, through direct involvement, a process of value creation for the stakeholders employing innovation to achieve goal and organization performance. Communicative in leadership develop certain knowledge and skills in order to be efficient in contributing to school effectiveness. Four leadership communicative have been identified, communication through processes, communication through structures, communication through social interaction and communication environment.

The result in this study not supported the literature by Musa and Fontana (2017) that motivational of entrepreneurial leaders related to the human action within the organization that affects both motivation and cognition of people in the organization performance. Motivation leaders play a critical role in the entrepreneurial process toward the organization achievement. It addresses the ability to motivate people in the organization, to understand the needs of the organization, to maintain an entrepreneurial spirit in people within the organization and to have the self-confidence to influence others. Motivational leaders explain the process by which charismatic leader behaviors cause profound transformational effects on followers. The result highlighted that the school leaders still weak in present the argument that charismatic leadership has its effects by strongly engaging followers self-concepts in the interest of the mission articulated by the leader. Therefore, the motivational leaders need to testable propositions about the behavior of charismatic leaders and their effects on followers, the role of followers values and orientations in the charismatic relationship and organizational conditions that favor the emergence and effectiveness of charismatic leaders.

Next the personal of entrepreneurial leaders dimension also showed a significant relationship to the performance. The personal result support the hypothesis in chapter two mentioned that performance deals with the personal skills to organize the needed resources and enact the role of framing the challenge, emotional stability at the individual level, passion and the commitment of the organization to entrepreneurial activities. The creativity, proper resource allocation and discipline in the personal of the entrepreneurial leaders will enhance the 
organization performance (Hejazi et al., 2012). The personal dimension of entrepreneurial leadership highlighted of the strongest of resilience in sustainable leaders. The resilience sustainable leaders show that leaders will adopt different approaches when faced with adversity and that there is a direct relationship between the stress of the leader's job and their ability to maintain resilience in the face of prolonged contact with adversity. Strategic of entrepreneurial leaders also show that significant relationship to the performance. Musa and Fontana (2017) mentioned that strategic refer to the ability to determine the organization system in a comprehensive manner taking into account resources, people and strategy toward organization success. The strategic leaders also addresses strategic thinking that entrepreneurial leaders must have to ensure the vision of future possibilities that is shared, so that the organization will have a sense of direction, destiny, discovery and goals achieve. In addition some school leaders are able to illustrate future events and prepare to deal with unforeseen circumstances. Based on the discussion on the result, conclude that the overall of entrepreneurial leadership are significant towards school performance in Malaysia. However, four dimensions of entrepreneurial leadership are significant relationship towards school performance and four dimensions are not significant relationship toward school performance. As the conclusion, conclude that leaders in schools need to practice the behaviour of entrepreneur such as proactiveness, creativities, innovative, communicative, strategic, motivational, personal and risk taking in order to overcome the constraints in the school effectiveness, particularly in relation to the required resources and increase the performance.

The finding of this study also hypothesized that sustainability leadership can be a new variable of leadership. This result also agreed a literature by Suriyankietkaew et al., (2014) that sustainability in competence and control the leadership and reputation in the organization. Furthermore, sustainability also shows significance relationship between leadership and innovative work behaviour (Kantabutra et al., 2013). The findings also supported by Kantabutra et al, (2013) that sustainability also influence of leadership on the engagement of effective organization. The resilience of sustainability leadership in this study has a significance to the school performance (Opoku et al., 2015). The resilience of sustainability leadership can be seen as the respective cause and effect of insinuating that leaders can have an influence on the empowering experiences of the subordinates developmental (Horward \& Irving, 2014). The result also supports by Dartey- Baah, (2015) that resilience effects the relationship between transformational leadership and followers' welfare. The findings in this study show that decision making of sustainability leadership also has significant relationship to the school performance. The hypothesis in chapter two mentioned that there are essentially two types of sustainability leadership given as resilience and decision making (Metsamuuronen et al., 2013; Avery et al., 2011). Empirical finding also agreed that sustainability and leadership will enhance subordinate work motivation and performance through the delegating authority for job related to decision making (Metsamuuronen, Kuosa \& Laukkanen, 2013). Benn et al., (2013) mentioned that emphasize on leadership and sustainability in education context is in similar fashion for organization success. The previous studies also give the suggestion that leadership influences sustainability organization through sustain them (Kantabutra et al., 2013). The finding of decision making in this study highlighted that the decision leaders in school organization to are very important for the school performing.

This study contributes the resilience of sustainability leadership and the result showed us the significant relationship toward school performance. Therefore, the result approves that resilience part of sustainability leadership elements. Resilience of sustainability leadership can affect school organization by articulating clear organization future goals, generating 
teachers staff enthusiasm for worthy causes and expressing high performance expectation. Resilience of sustainability leadership inversely associated with perceived crisis proneness. Sustainability leadership components including resilience are found to be significantly related to innovation performance. Accordingly, when a leader perceives that their requirements are meaningful and personally valuable, they can increase their achievement by willingly spending time and effort necessary to thoroughly identify a problem, search for extensive information, and generate multiple ideas from different perspectives. The theory of resilience leadership, the broader concept of leadership is quite complex to define or to assign a generic definition. Resilience leaders should provide some understanding as to what resilience leadership is basically about. This is in view of the fact that several relationships have been found to exist between leadership and organisational outcomes such as organisational culture. From the definition, can then suggest that resilience leadership is one that is able to sustain an organization or a groups competitive advantage over time through its ability to perform two tasks simultaneously, deliver excellent performance against current goals and effectively innovate and adapt to rapid, turbulent changes in technologies. In other words, resilience leadership can be defined as one that is both performance oriented and change oriented and thus pays attention to the meeting of organizational goals and also focused on initiating and managing change within the organization to suit the demands of both the internal and external organizational environment.

According to Farrar (2017) mentioned the challenges leaders face in today organizational environment can be termed as wicked problems. It is explains that these wicked problems are characterized by their novelty and uniqueness. They are socially complex and each stakeholder may have a different understanding and desired outcome. They are messy and do not have one solution. They cannot fully be solved as there is generally no clear sense of what the problem actually is and solving one problem may well cause another. Adapt to the school organization, school leaders would have to adopt unusual and innovative means to provide direction, rather than using the same approaches in solving what she terms tame problems which are common day today organizational problems. As the conclusion, the high performance and excellence cluster school also can sustain a performance if the leaders practice the knowledge of resilience. Therefore, this leadership style is important to increase and sustain the performance of the school organization

\section{Directions for Further Research}

In the future, there are several directions for the researchers to follow.

Leadership 4.0 need to be explored in full research and articles because there is limited study focused on leadership 4.0. Leadership 4.0 one of part in Industrial Revolution 4.0 and the first phase from six of Industry 4.0 roadmap The first phase of Industrial Revolution 4.0 is strategic management, which starts with defining industry 4.0 short term, medium term and long-term strategies. These strategies should be defined in time-based plan and describe it needs to go and how to get there, based on the industry 4.0 pre-set vision and plans. Digitization and industry 4.0 transition require committed leadership and fundamental resource allocation (Schumacher et al., 2016).

Entrepreneurial leadership for the future research needs to adapt about the eight dimensions of this leadership towards profit or non-profit organization. The next study also makes a research about entrepreneurial leadership towards school funds in public or private school in Malaysia. The entrepreneurial leadership research is limited study in public or private school. 
Sustainability leadership also need to explore by the new study in school organization. The elements practices to produce a set of twenty-three sustainability leadership practices by Avery and Bergsteiner (2011) need to be explore. The twenty there practices include of developing people, organizational change, labor relations, financial market orientation, retaining staff, responsibility for environment, succession planning, social responsibility (CSR), valuing staff, stakeholders, CEO and top team, vision role in the business, ethical behaviour, decision making, long or short term perspective, self-management, team orientation, culture, knowledge sharing and retention, trust, innovation, staff engagement and quality. The twenty-three practices introduce by Avery and Bergsteiner (2011) need to adapt in public or private school in Malaysia.

The future research can attempt to use additional theories such as LMX in order in enhance the proposed a new leadership align by leadership 4.0 toward performances or achievement in organization. The LMX theory occupies a unique position among leadership theories because of its focus on the dyadic relationship between leader and follower. LMX theory was originally referred to as Vertical Dyad Linkage (VDL) theory (Dansereau, Graen \& Haga, 1975). According to VDL approach, leaders and followers develop dyadic relationships and leaders treat individual followers differently, resulting in two groups of followers as an in group and out group. The group consists of a small number of trusted followers with whom the leader usually establishes a special higher quality exchange relationship. The out group includes the remaining followers with whom the relationship of the leader remains more formal.

The framework can be tested in private school in Malaysia on the basis orientation rather customer satisfaction orientation. In the private school context of profit orientation, the framework could be enhanced by including the competitive pressure variable and including the competitive advantage and sustainability to the research framework.

\section{References}

Anthony, S., Said, H., Mohamad, I., \& Mokhtar, M. (2015). Self-efficacy belief as a practical and parsimonious evaluation criterion in school leadership training. Mediterranean, Journal of Social Sciences, 6(1), 20.

Avery and Bergsteiner (2011), "Sustainable Leadership Practices for Enhancing Business Resilience and Performance", Strategy and Leadership, Vol.39 No.3 pp 5-15. Doi: $10.1108 / 10878571111128766$

Banker, R. D. and Tripathy R. M. A. (2014), "Does a differentiation strategy lead to more sustainable financial performance than a cost leadership strategy?", Management Decision, 52(5), $872-896$.

Benn, S. and Metcalf, L. (2013), "Leadership for Sustainability: An Evolution of Leadership Ability", Journal of Science and Business, pp 369-384. Doi: 10.1007/s10551-0121278-6

Becherer, R. C., M. E. Mendenhall, and K. F. Eickhoff (2008). "Separated at Birth: An Inquiry on the Conceptual Independence of the Entrepreneurship and the Leadership Constructs," New England Journal of Entrepreneurship 11(2), 13-27.70

Burnes, B. and Donnell, H. (2011), "What Can Business Leaders From Sport? International Journal of Sport Business and Management, Vol, No.1, pp 12- 27. Doi: $10.1108 / 20426781111107144$

Bush, T., and Glover, D. (2012). Distributed leadership in action: Leading high performing leadership teams in English schools. School Leadership \& Management, 32(1), 21-36. 
Castelli, D.M. (2015), "Contextualizing Physical Literacy in the Environment: The Challenges", Journal of Sport \& Health Science, Vol 4, No. 2, pp 156-163. Doi: 10.1016/j.jshs.2015.04.003

Chen, M.H. (2007), "Entrepreneurial Leadership and New Ventures: Creativity on Entrepreneurial Teams. Creativity \& Innovation Management, Vol.16 No.3, pp 239249

Connor, Kathryn M., and Jonathan RT Davidson. (2003), "Development of a new resilience scale: The Connor-Davidson resilience scale (CD-RISC)." Depression and Anxiety 18, no. 2 (2003): 76-82.

Cogliser, C.C. and Schriesheim, C.A. (2000), "Exploring Work Unit Context and Leader Member Exchange : A Multi-Level Perspective", Journal of Organizational Behaviour, Vol. 21 No.5, pp 487-511.

Dartey- Baah, K. (2015). "Resilient Leadership: A Transformational - Transactional Leadership Mix", Journal of Global Responsibility, Vol.6 No.1, pp 99-112. Doi 10.1108/JGR-07-2014-0026

Dansereau, F.,Graen, G.B. and Haga, W.(1975), "A Vertical Dyad Linkage Approach to Leadership in Formal Organization," Organizational Behaviour \& Human Performance Journal, 13, 46-78.

D'Intino, R. S., T. Boyles, C. Neck, and J. R. Hall (2008). "Visionary Entrepreneurial Leadership in the Aircraft Industry; The Boeing Company Legacy," Journal of Management History 14(1), 39-54

Eyal, O. and Inbar, D.E. (2013), "Developing a Public-School Entrepreneurship Inventory: Theoretical Conceptualization and Empirical Examination", International Journal of Behaviour and Research, Vol.9 No.6, pp 221-244. Doi: 10.1108/13552550310501356

Eilers, H., Chong, W., Kim, J., Naganathan, H. and Glavinich, T.E. (2016), "Impact of Sustainability on Business Performance and Strategy for Commercial Building Contractors",World Journal of Entrepreneurship Management and Sustainable Development, Vol. 12 No.4, pp 323-343. Doi: 10.1108/WJEMSD-07-2016-0032

Farrar, J.J. (2017) "Resilient leadership", International Journal of Emergency Services, Vol. 6 Issue: 3, pp.238-246. https://doi.org/10.1108/IJES-07-2017-0040

Fernald, L. W. J., G. T. Solomon, and A. Tarabishy (2005). "A New Paradigm: Entrepreneurial Leadership," Southern Business Review 30(2), 1-10.

Gerard, L., McMilan, J. and D'Annunzio-Green, N. (2017), "Conceptualising Sustainable Leadership", Industrial and Commercial Training, Vol.49 No.3, pp 116-126. Doi: 10.1108/ICT-12-2016-0079

Gilchrist, A. (2016), Industry 4.0: The Industrial Internet of Things, Springer, Heidelberg.

Gupta,V., MacMillan, I.C. and Surie,G. (2004), "Entrepreneurial Leadership: Developing and Measuring a Cross-Cultural Construct", Journal of Business Venturing, Vol. 19 No.2 pp 241-260. Doi:10.1016/S0883-9026(03)00040-5

Hallinger, P., \& Chen, J. (2015). Review of research on educational leadership and management in Asia: A comparative analysis of research topics and methods, 19952012. Educational Management Administration and Leadership, 43(1), 5-27. Doi: $10.1177 / 1741143214535744$

Herrera-Cano, C. (2016), "Disaster Risk Management in Business Education Entrepreneurial Formation for Corporate Sustainability" pp. 33 - 48 - ISSN 1692-0279. eISSN 22564322. DOI: 10.17230/ad-minister.28.2

Hejazi, S. A. M., Malei, M. M. and Naeiji, M. J. (2012), "Designing a Scale for Measuring Entrepreneurial Leadership in SMEs", International Conference on Economics, Marketing and Management, IPEDR, Vol.28 No.2, pp 71-77. 
Hooi, H. C., Ahmad, N. H., Amran, A., and Rahman, S. A. (2016). The functional role of entrepreneurial orientation and entrepreneurial bricolage in ensuring sustainable entrepreneurship. Management Research Review, 39(12), 1616-1638.

Hocevar, M.A., Janzen, M.I. and Wilson, C.L. (2012), "Leadership from ground up: Effective schooling in traditionally low performing school".

Howard, C.S and Irving, J.A. (2014), "The Impact of Obstacles Defined by Developmental Antecedents on Resilience in Leadership Formation", Management Research Review, Vol. 37 No.5, pp 466 - 478. Doi: http://dx.doi.org/10.1108/MRR-03-2013-0072

IAB. (2014). NPQEL Menjana Kepemimpinan Masa Hadapan: Menggilap Permata [NPQEL Generating Future Leaders: Enhancing Gems]. Genting Highlands: Author.

Jena, S.and Sahoo, C.K. (2014), "Improving Managerial Performance: A Case Study on Entrepreneurial and Leadership Competencies", Journal of Industrial \& Commercial Training, Vol. 46 No.3, pp 143-149. Doi:10.1108/ICT-10-2013-0066 281

Jones, M., \& Harris, A. (2014). Principals Leading Successful Organizational Change: Building Social Capital Through Disciplined Professional Collaboration. Journal of Organizational Change Management, 27(3), 473-485. Doi:10.1108/JOCM-07-20130116

Kansikas, J., Laakkonen, A., Sarpo, V.and Kontinen, T.(2012), "Entrepreneurial Leadership and Familinies as Resources for Strategic Entrepreneurship", International Journal of Entrepreneurial Behaviour \& Research, Vol.18 No.2, pp 141-158. Doi: 10.1108/ijebr.2012.16018baa.001

Kantabutra, S. and Saratun, M. (2013), "Sustainable Leadership: Honeybee Practices at Thailand's Oldest University", International Journal of Educational Management, Vol.27 No 4, pp 356-376. Doi 10.1108/09513541311316304

Kempster, S.J. \& Cope, J. (2010), "Learning to Lead in The Entrepreneurial Context," Journal of Entrepreneurial Behaviour and Research", Vol 16 No 1, pp 5-34. Doi: $10.1108 / 13552551011020054$

Kozlowski, R.(2014a). "Entrepreneurial Leadership as a Cognitive Construct for Effective Support in the Implementation of Decision-Making Opportunities", Journal of Management, Vol. 68, pp 61-70.

Kurland, H., Peretz,H. and \& Lazarowitz, R.H.(2010), "Leadership Style and Organizational Learning: The Mediate Effects of School Vision", Journal of Educational Administration Vol.48 No. 1, pp 7-30. Doi :10.1108/09578231011015395

Leithwood, K., \& Sun, J. P. (2012). "The Nature and Effects of Transformational School Leadership: A Meta-Analytic Review of Unpublished Research. Educational Administration Quarterly, 48(3), 387-423. Doi:10.1177/0013161x11436268

Liao, Y., Deschamps, F., Loures, E.d.F.R. and Ramos, L.F.P. (2017), "Past, present and future of Industry 4.0-a systematic literature review and research agenda proposal", International Journal of Production Research, Vol. 55 No. 12, pp. 3609-3629.

Luoh, H-F.,Tsaur, S-H. Tang, Y-Y. (2014), "Empowering Employees: Job Standardization and Innovative Behavior", International Journal of Contemporary Hospitality Management, Vol. 26 No.7, pp 1100 - 1117. Doi: 10.1108/IJCHM-03-2013-0153

Malaklolunthu, S., \& Shamsudin, F. (2011), "Challenges in School-Based Management: Case of a 'Cluster School' in Malaysia", Procedia-Social and Behavioral Sciences, 15, 1488-1492. Doi: 10.1016/j.sbspro.2011.03.316

MacKenzie, S.B., \& Podsakoff, P.M (2012). Common Method Bias in Marketing Causes, Mechanism and Procedural Remedies. Journal of Retailing, 88 (4), 542-555. 
Marshall, A. and Ojiako, U. (2015), "A realist Philosophical Understanding of Entrepreneurial Risk-Taking”, Society and Business Review, Vol. 10 No. 2, pp. 178193. Doi: $10.1108 /$ SBR-10-2014-0047

Mastrangelo,A.,Eddy, E.R.and Lorenzet, S.J. (2014), "The Relationship Between Enduring Leadership and Organizational Performance", Leadership \& Organization Development Journal, Vol. 35 Iss: 7, pp.590 - 604. Doi:10.1108/LODJ-08-2012 0097

McGrath, R. G., and I. C. MacMillan (2000). The Entrepreneurial Mindset. Boston: Harvard Business School Publishing.

Men, L.R. and Stacks, D.W. (2013), "The Impact of Leadership Style and Employee Empowerment on Perceived Organizational Reputation," Journal of Communication Management, Vol. 17 No 2, pp171-192. Doi: 10.1108/13632541311318765

Metsämuuronen, J., Kuosa, T. and Laukkanen, R. (2013), "Sustainable Leadership and Future-Oriented Decision Making in the Educational Governance - a Finnish Case", International journal of Contemporary Hospitality Management, Vol. 27 No.4, pp 402-424. Doi: http://dx.doi.org/10.1108/09513541311316331

Mitchelmore,S. and Rowley, J. (2010), "Entrepreneurial Competencies : A Literature Review and Development Agenda", International Journal of Entrepreneurial Behaviour \& Research, Vol.16 No.2, pp 92-111

Mumford, M. D., G. M. Scott, B. Gaddis, and J. M. Strange (2002). "Leading Creative People: Orchestrating Expertise and Relationships, "The Leadership Quarterly 13(6), 705-750.

Musa, S. and Fontana A. (2014), "Measuring Entrepreneurial Leadership in Innovation Management” The ISPIM Asia -Pacific Innovation Forum 2014, ISPIM, Singapore.

Musa, S. and Fontana A. (2017) "The Impact of Entrepreneurial Leadership on Innovation Management and its Measurement Validation", International Journal of Innovation Science, Vol.9 No 1, pp 2-19. Doi: 10.1108/IJIS-05- 2016-0004

Ng, W. and Thorpe, R. (2010), "Not Another Study of a Great Leaders: Entrepreneurial Leadership in a Mid-Sixed Family Firm for it's Further Growth and Development", International Journal of Entrepreneurial Behaviour \& Research, Vol.16 No.5, pp 457-476

Opoku, A., Ahmed, V. and Cruickshank, H. (2015), "Leadership style of sustainability professionals in the UK construction industry", Built Environment Project and Asset Management, Vol. 5, No. 2, pp. 184-201.

Park, J.H. (2012), “The Effects of Principal's Leadership Style on Support for Innovation: Evidence From Korean Vocational High School Change", Journal of Asia Pacific Education, Vol 16 No.1, pp 5-34. Doi: 10.1007/s12564-011-9182-9

Pihie, Z.A.L., Asimiran, S. and Bagheri, A. (2014), "Entrepreneurial Leadership, Practices and School Innovativeness", South African Journal of Education, Vol.34 No.1. http://www.sajournalofeducation.co.za

Rahimah, H. A., \& Ghavifekr, S. (2014). School Leadership for the 21st century: A Conceptual Overview. Malaysian Online Journal of Educational Management, 2(1), 48-61

Renko, M.,Tarabishy, A.E, Carsrud, A.L. and Brannback, M. (2015), "Understanding and Measuring Entrepreneurial Leadership Style", Journal of Human Resources Management, Vol.53 No.1, pp 54-74. Doi: 10.1111/jsbm.12086

Ruvio, A., Rosenblatt, Z. And Hertz-Lazarowitz. R. (2010), "Entrepreneurial Leadership Vision in Non-profit vs. or-Profit Organizations", Leadership Quarterly, Vol.21 No.1, pp 44-158.

Sammon, P., Hillman, J. and Mortimore, P. (1995), "Key Characteristics Of Effective School : A Review of School Effectiveness Research”, A Report by the Institute of Education 
for the Office for Standard in Education. London: University of London. (ERIC Document Reproduction No ED 231182)

Schumacher, A., Erol, S. and Sihn, W. (2016), "A maturity model for assessing Industry 4.0 Readiness and maturity of manufacturing enterprises", Procedia CIRP, Vol. 52 No. 1, pp. 161-166.

Scott, S.G., \& Bruce, R.A (1995), Decision-making style: The development and assessment of new measure. Educational and Psychological Measurement, 55, (5a), 818 - 831.

Shaked, H. and Schechter, C. (2014), "Systems school leadership: exploring an emerging construct", Journal of Educational Administration, Vol. 52 No. 6, pp. 792-811. DOI 10.1108/JEA-07-2013-0081

Soane, E., Butler, C.,and Stanton, E. (2015).“Followers Personality, Transformational Leadership And Performance. Sport, Business and Management: An International Journal, 5(1), 65-78. https://doi.org/10.1108/SBM-09-2011-0074.

Smith, B., Dalen, J., Wiggins, K., Tooley, E., Christopher, P. and Benard, J. (2008), "The Brief Resilience Scale: Assessing the Ability to Bounce Back". International Journal of Behavioral Medicine, 15(3), 194-200.

Strand, R. (2014), "Strategic Leadership of Corporate Sustainability", International Journal of Science and Business, pp, 687-706. Doi: 0.1007/s10551-013-2017-3

Suriyankietkaew, S.and Avery, G.C. (2014), "Employee Satisfaction and Sustainable Leadership Practices in Thai SMEs", Journal of Global Responsibility, Vol.5 No.1, pp 160-173. Doi: 10.1108/JGR-02-2014-0003

Suriyankietkaew, S. (2016), "Effects of Sustainable Leadership on Customer Satisfaction: Evidence from Thailand", Asia Pacific Journal of Business Administration, Vol. 8 No.3, pp 245-259. Doi: 10.1108/APJBA-03-2016- 0031

Thornberry, N. (2006). Lead Like an Entrepreneur: Keeping the Entrepreneurial Spirit Alive within the Corporation. Fairfield, PA:McGraw Hill.

Tie, F. H. (2012). Leadership for learning in Malaysian schools. In T. T. A. J. MacBeath (Ed.), International handbook of leadership for learning (pp. 419-429). Dordrecht Heidelberg: Springer.

Tideman, S.G. (2016), “Gross National Happiness: Lessons for Sustainability Leadership", Journal of Global Business Research, Vol.5 No.2 pp 190-213. Doi: 10.1108/SAJGBR-12-2014-0096

Tierney, P., and S. M. Farmer (2004). "The Pygmalion Process and Employee Creativity", Journal of Management 30(3), 413-432.

Ustundag, A. and Cevikcan, E. (2017), Industry 4.0: Managing the Digital Transformation, Springer, Heidelberg.

Verma, N., Bhat, A. B., Rangnekar, S., and Barua, M. (2015), "Association between leadership style and decision-making style in Indian organisations". Journal of Management Development, 34(3), 246-269

Vogel-Heuser, B. and Hess, D. (2016), "Guest editorial Industry 4.0-prerequisites and visions", IEEE Transactions on Automation Science and Engineering, Vol. 13 No. 2, pp. 411-413.

Wang, C-J. (2014), "Do Ethical and Sustainable Practices Matter? Effects of Corporate Citizenship on Business Performance in the Hospitality Industry", International Journal of Contemporary Hospitality Management, Vol. 26 No. 6, pp 930 - 947. Doi: http://dx.doi.org/10.1108/IJCHM-01-2013-0001

Xaba, M. and Malindi, M. (2010), "Entrepreneurial Orientation and Practice: Three Case Example of Historically Disadvantaged Primary School", South Africa Journal of Education, Vol. 30 No.3, pp75-89 